\title{
Family influence on the nutritional status and eating habits of six to nine year-old children
}

\author{
Influência familiar no estado nutricional \\ e hábito alimentar de crianças
} de seis a nove anos

\author{
Gabriela Pap da SILVA1 1 0000-0001-9949-0705 \\ Sebastião de Sousa ALMEIDA ${ }^{1}$ ID 0000-0002-1551-9062 \\ Telma Maria BRAGA COSTA 1 ID 0000-0002-6154-5667
}

A B S TR A C T

\section{Objective}

To investigate whether caregivers' attitudes, beliefs, practices, alimentary habits, and nutritional status influence the alimentary habits and nutritional status of children aged six to nine years.

\section{Methods}

This cross-sectional study included 164 children and a family member (caregiver) each ( $n=164)$, carried out in the family health units of the municipality of Ribeirão Preto (SP), Brazil. Weight and height measurements were performed; each child was then evaluated by the application of both the Child Feeding Questionnaire and $24 \mathrm{~h}$ recall (for calculating the Healthy Eating Index Revised), in addition to the assessment of adherence to healthy eating steps of the Ministry of Health, through a questionnaire.

\section{Results}

The results showed that the prevalence of being overweight was $18.3 \%$ in children and $32.9 \%$ in caregivers, and the prevalence of obesity was $15.9 \%$ and $37.9 \%$, respectively. Most of the 56 children categorized as overweight also had overweight caregivers $(82.1 \% ; n=46)$. Concerns regarding children's weight control were higher among caregivers

\footnotetext{
1 Universidade de São Paulo, Faculdade de Filosofia, Ciências e Letras de Ribeirão Preto, Departamento de Psicologia. Av. Bandeirantes, n. 3900, Vila Monte Alegre, 14040-901, Ribeirão Preto, SP, Brasil. Correspondence to: S.S. ALMEIDA. E-mail: <sebalm@usp.br>. Article elaborated from dissertation by GP SILVA, entitled "Avaliação da influência familiar no estado nutricional e hábito alimentar de crianças de seis a dez anos”. Universidade de São Paulo; 2017.
}

How to cite this article

Silva GP, Almeida SS, Braga Costa TM. Family influence on the nutritional status and eating habits of six to nine year-old children. Rev Nutr. 2021;34:e200165. https://doi.org/10.1590/1678-9865202134e200165 


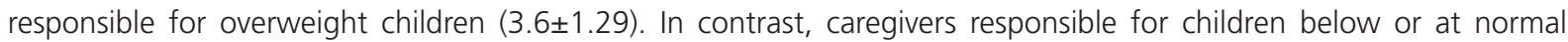
weight demonstrated a greater tendency toward getting children to eat $(3.3 \pm 0.97$ and $3.9 \pm 0.99$, respectively). The average score; of the children's Brazilian Healthy Eating Index Revised (50.0 \pm 13.6$)$ was similar to that of their caregivers $(56.5 \pm 12.1)$.

\section{Conclusion}

Caregivers have a direct influence on the nutritional status and eating habits of children; therefore, they should be targeted in the processes of nutritional intervention for the prevention and treatment of childhood obesity.

Keywords: Child nutrition. Feeding behavior. Food consumption. Nutritional status. Pediatric obesity.

\section{R E S U M O}

\section{Objetivo}

Este estudo se propôs a investigar se atitudes, crenças, práticas, hábitos alimentares e estado nutricional dos responsáveis influenciam os hábitos alimentares e o estado nutricional de crianças de 6 a 9 anos.

\section{Métodos}

Estudo transversal com 164 crianças e um respectivo responsável por sua alimentação ( $n=164)$, desenvolvido em Unidades de Saúde da Família do município de Ribeirão Preto (SP). Realizaram-se aferição de peso e estatura, aplicação do Questionário de Alimentação da Criança e Recordatório Alimentar de 24 horas (para cálculo do Índice de Qualidade da Dieta Revisado), além de verificação da adesão aos Passos da Alimentação Saudável do Ministério da Saúde, por meio de um questionário.

\section{Resultados}

Os resultados obtidos mostraram que as prevalências de sobrepeso foram de 18,3\% nas crianças e de 32,9\% nos responsáveis, e as prevalências de obesidade foram de 15,9\% e 37,9\%, respectivamente. Os responsáveis da maioria das 56 crianças que apresentaram excesso de peso também tinham excesso de peso (82,1\%; n=46). A preocupação

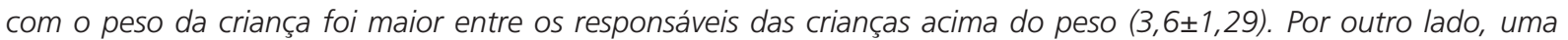
maior pressão para comer foi identificada entre os responsáveis com crianças com baixo peso ou peso normal (3,3 $\pm 0,97$

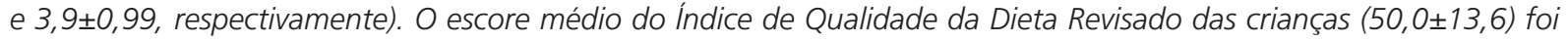
muito similar ao dos responsáveis $(56,5 \pm 12,1)$.

\section{Conclusão}

Os responsáveis exercem influência direta no estado nutricional e hábitos alimentares das crianças, devendo ser alvos nos processos de intervenção nutricional para a prevenção e o tratamento da obesidade infantil.

Palavras-chave: Alimentação infantil. Comportamento alimentar. Consumo de alimentos. Estado nutricional. Obesidade pediátrica.

\section{NTRO D U CTIO N}

Obesity is characterized by excessive accumulation of fat at a level that could be malign to health $[1,2]$. Studies indicate that childhood obesity is a risk factor to developing dyslipidemia and insulin resistance even in childhood [3]. According to global estimates, in 2016, more than 340 million children and adolescents (between 5 and 19 years old) were overweight or obese [1]. There was a pronounced increase in the proportion of overweight children in Brazil, mainly in the age group of 5 to 9 years of age, between 1989 and 2009. Among boys in this age group, overweight individuals reached $34.8 \%$, and among girls, this index reached $32 \%$, whereas the overall obesity rate among boys was $4.1 \%$ and among girls $11.8 \%$ [4].

Obesity has a multifactorial character, among its main causes, and environmental factors stand out, such as socioeconomic conditions, lifestyle, and eating habits [2,5-9]. Several instruments are used to assess food intake, which is one of the aspects of eating behavior $[5,8,10-19]$. However, there is no foolproof 
assessment of the food consumption method $[20,21]$. The 24 -hour recall is the most suitable approach to quantify and assess food and nutrient intake [7,18,22,23].

Eating behavior is complex: it is not restricted to consumption patterns but encompasses everything from choice and purchase to food preparation and the act of eating. Eating behavior involves several environmental, nutritional, psychological, social, and cultural factors [2,18,24-26]. Nutritional knowledge alone does not guarantee healthy eating habits because the actual behavior is dependent on food beliefs, taboos, and so on $[25,27]$. Children's eating behavior is most susceptible to external interference because they are not the ones purchasing and preparing the food they consume $[11,17,26-29]$, in addition to attitudes, control practices, and beliefs of family members in relation to their food that directly influence the construction of eating habits even in childhood $[9,15,25,30,31]$.

The influence of caregivers on children's nutritional status should be investigated and detailed in order to increase the possibilities of intervention in the family environment, which may impact the prevention and treatment of childhood obesity. Therefore, this study aimed to investigate the influence of attitudes, beliefs, and eating practices of those responsible, and their nutritional status, on the eating habits and nutritional status of children.

\section{METHODS}

This was a cross-sectional study that evaluated 164 children aged between 6 and 9 years, together with a caregiver responsible for feeding them $(n=164)$, who lived in the area covered by 1 of the 9 Family Health Units (FHU) in the city of Ribeirão Preto (SP), Brazil. The sample was defined based on the total number of children enrolled at FHU $(n=4,401)$ in the municipality. The sample size was established based on the variance of results from a pilot study [32].

The study received approval from the Ethics Committee (decision number CAAE n. 49127115.5.0000.5407). Data collection was performed by the principal researcher at the FHU between April and July 2016. The sampling process was random; children accompanied by the caregivers who attended the FHU during this period were invited to participate in the study. An interview was conducted in an FHU room, with both children and caregivers, and they also underwent anthropometric assessment (weight and height measurement).

A sample characterization questionnaire consisting of identification and sociodemographic data (age, gender, parent-child relationship) of the children and their respective caregivers was used. Weight and height were computed with a compact scale and stadiometer (digital scale, with a capacity of $180 \mathrm{~kg}$ and graduation of $100 \mathrm{~g}$ : stadiometer with a wooden ruler, extension up to $213 \mathrm{~cm}$, and accuracy of $0.1 \mathrm{~cm}$ ). For the measurements, the children and their caregivers were instructed to remove ornaments, shoes, items from the pockets and hair props, standing upright in the center of the device, with arms extended along the body and head at right angles to the neck, looking at a fixed point at eye level. The nutritional status evaluation was based on the Body Mass Index (BMI), respecting the cutoffs for age group children older than 5 years and adolescents up to 19 years old, adult caregivers (aged between 20 and 59 years) e elderly (60 years or older) [33].

The caregivers' nutritional status was established according to life phases (adolescent, adult, and elderly). Still, to enable better visualization of the parents' nutritional status $(n=164)$, the classification results were grouped and presented together through absolute and relative frequency as well as that of children. McNemar's test was applied to compare the children's nutritional status and their cares. 
To assess the viewpoints, attitudes, and practices of parents in relation to children's feeding and the possible relationship between these factors and child obesity, a Brazilian version of the Child Feeding Questionnaire (CFQ) was applied [34]. The CFQ consists of 31 questions, divided into 7 factors: 4 factors that measure the report of parents' beliefs regarding their child's obesity-prone diet (Perceived Responsibility, Perceived Parent Weight, Perceived Child Weight, and Concern About Child Weight) and 3 factors that measure parental control practices and attitudes about child feeding (Restriction, Pressure to Eat, and Monitoring) [34].

As proposed by the authors of the original as well as those of the Brazilian version, the 31 questions of the CFQ are rated on a 5-point range from 1 to 5. Each question was scored, and there ultimately emerged a mean score for each factor [34]. In this analysis, questions 11, 12, and 13 (concerning the child weight perception factor) were withdrawn because the ages of the children in this study did not make it possible to obtain answers to these questions for all children.

The Child Feeding Questionnaire score results are presented in terms of their median (Q1-Q3) and minimum-maximum values. The Kruskal-Wallis test was applied to establish the relationship between each of the 7 CFQ factors and the children's nutritional status. For CFQ factors that presented $p<0.05$, in the Kruskal-Wallis test (Factors 3, 4, and 6), Dunn's test was performed.

To evaluate the frequency of adherence to the Ministry of Health's 9 steps for a healthy diet, for both children and caregivers was used in the questionnaire by Vinholes et al. [35]. After determining each individual's adherence or non-adherence to each of the 9 steps, 3 categories were created: high adherence (adherence meets 7 to 9 steps), average adherence (adherence meets 4 to 6 steps), and low adherence (adherence meets no more than 3 steps). For associations between nutritional status and step adherence (both children and caregivers), Fisher's exact test was performed.

To evaluate the overall quality of children's and caregivers' diets, the $24 \mathrm{~h}$ recall technique, referring to the previous day's feeding, was applied. The $24 \mathrm{~h}$ recall was used to calculate the Brazilian Healthy Eating Index Revised (BHEI-R), the current Brazilian version of the Healthy Eating Index (HEI), originally developed in the United States. The BHEI-R has 12 elements: 9 of them are based on the food groups of the first Food Guide for the Brazilian Population (total cereals; whole grains; total fruits; whole fruits; total vegetables; dark green and orange vegetables and legumes; milk and derivatives; meat, eggs, and legumes; and oils), 2 components are nutrients (sodium and saturated fat), and the last component consists of calories from Solid Fats, Alcohols, and Added Sugars (SoFAAS) [36-40].

The Brazilian Healthy Eating Index Revised was calculated according to the instructions listed in the roadmap provided by the Food Consumption Assessment Research Group [41]. The final rating of the BHEI-R can range from 0 to 100 [38]. Three procedures were employed to draw conclusions from the BHEI-R evidence: (1) data were analyzed descriptively; (2) paired t-Student test (comparing the scores of children and their caregivers); and (3) individuals who obtained a final score greater than the third tertile were categorized with an adequate diet (BHEI-R $>61.7$ points for caregivers and BHEI-R $>57.0$ for children). All data were computed and analyzed using statistical tests appropriate to the objectives and through descriptive statistics. The significance level was set at 5\% $(p<0.05)[42-44]$.

\section{RE S U L T S}

The sample consisted of 164 children aged 6 to 9 years (and their respective caregivers): 96 (58.5\%) were female and $68(41.5 \%)$ were male. The age division was: 6-7 years and 8-9 years, both with 82 $(50 \%)$ children. Of the 164 responsible, the majority $(n=158 ; 96.3 \%)$ were female. The age groups of the 
caregivers were: $18-29$ years $(n=34 ; 20.7 \%), 30-44$ years $(n=88 ; 53.7 \%), 45-59$ years $(n=26 ; 15.8 \%)$, and 60 years or older $(n=16 ; 9.8 \%)$. Mothers represented most of the caregivers $(n=123 ; 75.0 \%)$, but there were also some grandparents $(n=28 ; 17.1 \%)$, fathers $(n=6 ; 3.6 \%)$, and other caregivers $(n=7,4.3 \%)$.

The Table 1 presents the categorization of the nutritional status of the children and their caregivers, separated by age group, and Table 2 shows an association $(p<0.01)$ between the nutritional status of the children and their caregivers. It is noteworthy that of the 56 children who were overweight (overweight or obese), 46 caregivers were overweight, and $72.3 \%$ of the caregivers who had an adequate weight also had their child with an appropriate weight.

Table 1 - Nutritional status of the participants. Ribeirão Preto (SP), Brazil, 2016.

\begin{tabular}{|c|c|c|}
\hline Nutritional status & $n$ & $\%$ \\
\hline Children & 164 & 100 \\
\hline Severe thinness & 1 & 0.6 \\
\hline Thinness & 5 & 3.0 \\
\hline Normal & 102 & 62.2 \\
\hline Overweight & 30 & 18.3 \\
\hline Obesity & 18 & 11.0 \\
\hline Severe obesity & 8 & 4.9 \\
\hline Caregivers & 164 & 100 \\
\hline Underweight & 1 & 0.6 \\
\hline Normal weight & 47 & 28.6 \\
\hline Pre-obesity & 54 & 32.9 \\
\hline Obesity class I & 37 & 22.6 \\
\hline Obesity class II & 16 & 9.8 \\
\hline Obesity class III & 9 & 5.5 \\
\hline
\end{tabular}

Table 2 - Comparison between classification of the nutritional status of children and their respective caregivers. Ribeirão Preto (SP), Brazil, 2016.

\begin{tabular}{|c|c|c|c|c|c|c|c|c|c|}
\hline \multirow{3}{*}{ Nutritional status (Children) } & \multicolumn{9}{|c|}{ Nutritional status (Caregivers) } \\
\hline & \multicolumn{2}{|c|}{ Under-weight } & \multicolumn{2}{|c|}{ Normal weight } & \multicolumn{2}{|c|}{ Over-weight } & \multicolumn{2}{|c|}{ Total } & \multirow{2}{*}{$p$-value* } \\
\hline & $\mathrm{n}$ & $\%$ & $\mathrm{n}$ & $\%$ & $\mathrm{n}$ & $\%$ & $\mathrm{n}$ & $\%$ & \\
\hline Underweight & 0 & 0.0 & 3 & 6.4 & 3 & 2.6 & 6 & 3.7 & \\
\hline Normal weight & 1 & 100 & 34 & 72.3 & 67 & 57.8 & 102 & 62.2 & $<0.01$ \\
\hline Overweight & 0 & 0.0 & 10 & 21.3 & 46 & 39.6 & 56 & 34.1 & \\
\hline Total & 1 & 100 & 47 & 100 & 116 & 100 & 164 & 100 & \\
\hline
\end{tabular}

Note: For the classification of nutritional status, the cutoff points for each age group were considered and subsequently grouped. * McNemar's test: a significance level of $5 \%$.

The median values of the 7 factors of the CFQ were as follows: Perception of Responsibility: 4.3 (C195\% 1.3-5.0); Parental Weight Perception: 3.2 (C195\% 2.0-5.0); Perception of Child's Weight: 3.0 (CI95\% 1.7-5.0); Concern about the child's weight: 3.2 (CI95\% 1.0-5.0); Restriction: 3.3 (CI95\% 1.0-4.6); Pressure to Eat: 3.75 (C195\% 1.0-5.0); and monitoring: 4.0 (C195\% Cl 1.0-5.0). The results of the 7 factors of the CFQ were also separated according to children's nutricional status (see Table 3 for detailed results) in order to verify if any stronger correlations could be obtained. In Factor 3, the significant difference was between underweight and normal weight. In Factors 4 and 6, a statistically significant difference was only found between normal weight and underweight. 
Table 3 - Descriptive analysis of the 7 factors of the Child Feeding Questionnaire, with results separated by children's nutritional status. Ribeirão Preto (SP), Brazil, 2016.

\begin{tabular}{|c|c|c|c|c|c|c|c|c|}
\hline Factors of the CFQ & Child NS & $\mathrm{n}$ & Min & Q1 & M & Q3 & Max & $p$-value* \\
\hline \multirow[t]{3}{*}{ Perceived Responsibility } & Below weight & 6 & 3.3 & 4.0 & 4.8 & 5.0 & 5.0 & 0.50 \\
\hline & Suitable weight & 102 & 1.3 & 4.0 & 4.3 & 5.0 & 5.0 & \\
\hline & Overweight & 56 & 1.3 & 3.7 & 4.3 & 5.0 & 5.0 & \\
\hline \multirow[t]{3}{*}{ Perceived Parent Weight } & Below weight & 6 & 2.5 & 3.0 & 3.1 & 3.2 & 3.5 & 0.25 \\
\hline & Suitable weight & 102 & 2.0 & 3.0 & 3.0 & 3.2 & 4.7 & \\
\hline & Overweight & 56 & 2.2 & 3.0 & 3.2 & 3.5 & 5.0 & \\
\hline \multirow[t]{3}{*}{ Perceived Child Weight } & Below weight & 6 & 2.0 & 2.3 & 2.8 & 3.0 & 3.0 & $<0.01$ \\
\hline & Suitable weight & 102 & 1.7 & 3.0 & 3.0 & 3.0 & 3.7 & \\
\hline & Overweight & 56 & 2.3 & 3.0 & 3.0 & 3.3 & 5.0 & \\
\hline \multirow[t]{3}{*}{ Concern About Child Weight } & Below weight & 6 & 2.0 & 2.7 & 3.5 & 4.3 & 4.7 & $<0.01$ \\
\hline & Suitable weight & 102 & 1.0 & 1.7 & 2.7 & 3.7 & 5.0 & \\
\hline & Overweight & 56 & 1.0 & 2.5 & 3.7 & 5.0 & 5.0 & \\
\hline \multirow[t]{3}{*}{ Restriction } & Below weight & 6 & 1.6 & 2.5 & 2.7 & 3.7 & 4.0 & 0.44 \\
\hline & Suitable weight & 102 & 1.0 & 2.6 & 3.2 & 3.6 & 4.6 & \\
\hline & Overweight & 56 & 1.0 & 2.7 & 3.5 & 3.9 & 4.6 & \\
\hline \multirow[t]{3}{*}{ Pressure to Eat } & Below weight & 6 & 2.2 & 2.2 & 3.5 & 4.0 & 4.5 & $<0.01$ \\
\hline & Suitable weight & 102 & 1.0 & 3.5 & 4.0 & 4.7 & 5.0 & \\
\hline & Overweight & 56 & 1.0 & 2.0 & 2.5 & 4.0 & 5.0 & \\
\hline \multirow[t]{3}{*}{ Monitoring } & Below weight & 6 & 1.0 & 1.7 & 3.5 & 5.0 & 5.0 & 0.85 \\
\hline & Suitable weight & 102 & 1.0 & 3.0 & 4.0 & 5.0 & 5.0 & \\
\hline & Overweight & 56 & 1.0 & 3.0 & 4.0 & 5.0 & 5.0 & \\
\hline
\end{tabular}

Note: "Kruskal-Wallis test: a significance level of 5\%; CFQ: Child Feeding Questionnaire; M: Median; Max: Maximum; Min: Minimum; NS: Nutritional Status; Q1: $1^{\circ}$ Quartile; Q3: $3^{\circ}$ Quartile.

Table 4 shows the frequencies of adherence to healthy eating steps of children and caregivers separated by the nutritional status. To compare the variables (adherence levels and nutritional status), Fisher's exact test was performed, which showed an association between adequate weight and the levels of medium and high adherence $(p<0.01)$.

Table 4 - Absolute and relative frequency of parents' adherence to the 9 steps of healthy eating, separated by nutritional status. Ribeirão Preto (SP), Brazil, 2016.

\begin{tabular}{|c|c|c|c|c|c|c|c|c|c|}
\hline \multirow{3}{*}{ Level of adherence to the steps of healthy eating } & \multicolumn{8}{|c|}{ Nutritional status } & \multirow{3}{*}{$p$-value* } \\
\hline & \multicolumn{2}{|c|}{ Under-weight } & \multicolumn{2}{|c|}{ Normal weight } & \multicolumn{2}{|c|}{ Over-weight } & \multicolumn{2}{|c|}{ Total } & \\
\hline & $\mathrm{n}$ & $\%$ & $\mathrm{n}$ & $\%$ & $\mathrm{n}$ & $\%$ & $\mathrm{n}$ & $\%$ & \\
\hline Child & & & & & & & & & $<0.01$ \\
\hline High adherence(7-9) & 0 & 0.0 & 38 & 37.3 & 7 & 12.5 & 45 & 27.4 & \\
\hline Average adherence (4-6) & 5 & 83.3 & 64 & 62.7 & 41 & 73.2 & 110 & 67.1 & \\
\hline Little adherence (0-3) & 1 & 16.4 & 0 & 0.0 & 8 & 14.3 & 9 & 5.5 & \\
\hline Total & 6 & 100 & 102 & 100 & 56 & 100 & 164 & 100 & \\
\hline Caregivers & & & & & & & & & $<0.01$ \\
\hline High adherence (7-9) & 0 & 0.0 & 22 & 46.8 & 21 & 18.1 & 43 & 26.2 & \\
\hline Average adherence (4-6) & 1 & 100 & 24 & 51.1 & 87 & 75.0 & 112 & 68.3 & \\
\hline Little adherence (0-3) & 0 & 0.0 & 1 & 2.1 & 8 & 6.9 & 9 & 5.5 & \\
\hline Total & 1 & 100 & 47 & 100 & 116 & 100 & 164 & 100 & \\
\hline
\end{tabular}

Note: ${ }^{*}$ Fisher's exact test: significance level 5\%.

When comparing children's levels of adherence to the healthy eating steps with those of their respective caregivers, it was observed that for the 45 children who demonstrated high adherence, 21 (46.7\%) of the 
caregivers also demonstrated high adherence. Twenty-four (53.3\%) of the caregivers demonstrated average adherence, and none demonstrated low adherence. Among the 110 children who demonstrated average adherence, $84(76.4 \%)$ of the caregivers demonstrated average adherence, 20 (18.2\%) demonstrated high adherence, and only 6 (5.4\%) demonstrated low adherence.

The interval of the third tertile of the BHEI-R score, which indicates a healthy diet, was found to vary between 61.7 and 92.0 points for caregivers and 57.0 and 85.3 points for children. Female children obtained a higher mean BHEI-R score $(52.0 \pm 14.38)$ than male children $(47.3 \pm 11.97)$; this mean difference was approximately 4.7 points, and the difference between the 2 groups was found to be statistically significant $(p<0,05)$. Figure 1 shows caregivers' and children's dispersion indicators of the BHEI-R by age group. When a comparison was made between the paired data (paired $t$-test) of the BHEI-R of the children and their respective caregivers with the BHEI-R, the estimated difference was 6.5 points.

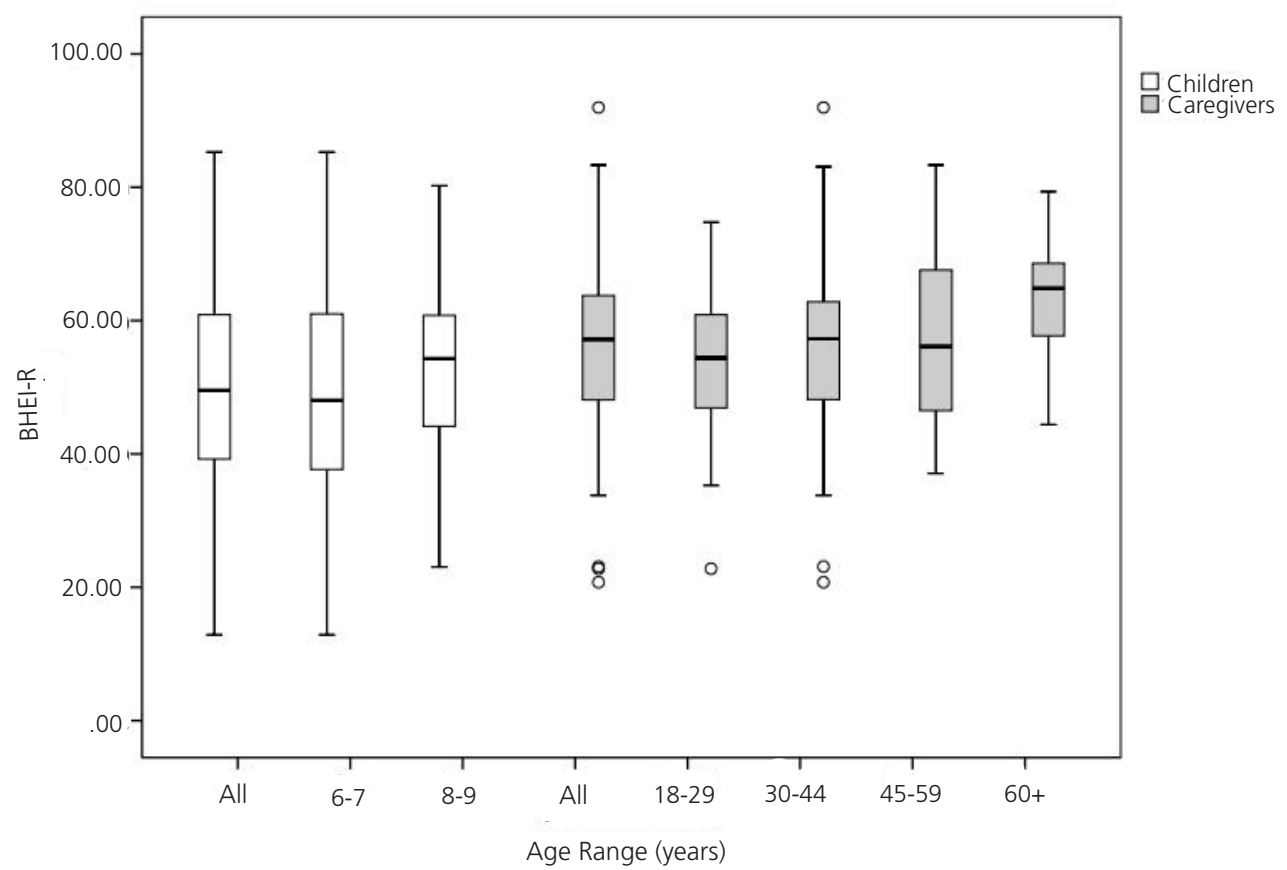

Figure 1 - Brazilian Healthy Eating Index Revised of caregivers and children, separated by age group. Ribeirão Preto (SP), Brazil, 2016. Note: BHEI-R: Brazilian Healthy Eating Index Revised.

\section{I S C U S S I O N}

The mean scores of the monitoring factor did not significantly differ among caregivers of children with different nutritional status, a pattern was noted: caregivers responsible for normal weight children had the highest score, followed by those responsible for overweight children. Lastly, caregivers who monitor less are those whose children are underweight, similar to other studies $[30,45]$.

It was evident that when restricting the consumption of certain foods, caregivers took into account the weight of their child. The highest mean of restriction practices was detected among caregivers responsible 
for children with severe obesity, followed by those caring for obese and overweight children $[3,30,46]$. This is consistent with the literature identifying this practice as a caregiver's first choice to control overweight children's consumption of unhealthy foods $[3,9]$. However, this practice is classified as dangerous in the long term because the child bases the choice and quantity of food on parental rules and not on knowledge about nutrition or indicators of hunger and satiety $[9,30,46]$.

The mean scores of CFQ factors in Karp's et al. [45] study were similar to the present study, with the greatest similarity in Perceived Responsibility (Karp et al. [45]: 4.3; present study: 4.2), showing that when working with a caregiver who is not necessarily the mother, it is possible to consider the individual most present in the daily life of the child and who may exert a greater influence on the eating habit, since it is he/ she who often selects, prepares, and makes available the foods that the child consumes.

A study showed that children/adolescents from the most dysfunctional families demonstrated the greatest interest in food (regardless of the parents' weight). Children who perceived their family environments as supportive and who had the freedom to express their feelings demonstrated a more controlled food intake and healthier eating styles [47].

Aiming to include children whose main caregiver is an adult other than the mother, some studies defined caregivers as those most involved in the care of the child [45-49]. However, the results of this study illustrated that women are still the main caregivers of children.

Lorenzato et al. [34] pointed out that children's nutritional status is correlated with that of their caregivers, reinforcing the importance of the family environment in the development of children's eating habits and, consequently, in their nutritional status. Other studies have shown that, in addition to genetic factors, many factors in the family environment can directly interfere with children's eating behavior, especially strategies adopted by those responsible for feeding them $[2,5,25,27,30]$.

Children's and caregivers' levels of adherence to the healthy eating steps were very similar $(67.1 \%$ of the children and $68.3 \%$ of the caregivers demonstrated average adherence). It is noteworthy that all children with normal weight demonstrated average or high adherence, while among caregivers with normal weight, only 1 demonstrated low adherence to the steps. Almost half of the caregivers who demonstrated high adherence were overweight, and these individuals may be inadequate in the amount of food consumed and not in quality.

It is to be noted that the ingestion of foods considered healthy, both by children and their caregivers, does not indicate the exclusion of high-calorie foods with low nutritional content $[8,11,50]$. One can also think about reverse causality, where the individual who identifies a health problem, such as being overweight, starts to look for a healthier diet as part of the treatment or prevention of diseases.

Among the children with high adherence $(n=45)$, a large proportion had normal weight $(n=38)$. Of the 112 children with average adherence, 84 caregivers also demonstrated average adherence. All children with high adherence had caregivers with average or high adherence. The similarity found between the levels of adherence to the steps of healthy eating for children and their caregivers suggests a similar eating pattern among family members. It should be emphasized that in a cross-sectional study, the results found cannot infer a causal relationship, or even that consumption data are considered usual because only a 2-hour recall was applied.

The mean of the children's BHEI-R score was lower than that of their caregivers, indicating a greater need for dietary modification. Among the children, the girls obtained significantly higher scores than boys $(p<0,05)$, similarly to findings of other studies $[10,51]$. Other studies using the BHEI-R have also demonstrated that a large percentage of individuals have a score that indicates the need for diet modification 
$[36,23]$. The pattern of food consumption by caregivers is increasingly pointed out as one of the factors associated with the child's food pattern, and this influence started even in early childhood [50].

Several explanations have been offered to account for individuals' eating behavior and nutritional status, particularly during childhood. Family-members have crucial importance in this regard because their attitudes and control practices affect children. Nonetheless, it is necessary to highlight and bring awareness to the fact that the causes of obesity exceed environmental factors.

It is not possible to jointly assess all aspects of the family influence on children's nutritional status and eating habits. In this context, a drawback of this research was to evaluate part of the spectrum of children's eating behavior and their respective caregivers. A second shortcoming worth mentioning was evaluating the eating behavior in a single day, which may not always correspond to the habitual behaviors of the sampled individuals.

\section{CONCLUSION}

The nutritional status and the caregivers' food consumption are associated with nutritional status and children's food consumption. Some control practices of caregivers in relation to the child's food, such as pressure to eat and restriction, were connected to the perception that the caregivers had in the context of the child's nutritional status, highlighting these common practices, but which can cause a loss in behavior development child's long-term diet.

\section{ACKNOWLEDGMENTS}

We are grateful to Dr. Daniela S. Sartorelli for her suggestions concerning one of the indices applied here (BHEI) and to Ms. Laura S. Paulino for her assistance with data gathering. This study was financed in part by the Coordenação de Aperfeiçoamento de Pessoal de Nível Superior (CAPES, Coordination of Superior Level Staff Improvement).

\section{CONTRIBUTORS}

GP SILVA contributed to the conception and design of the study, analysis and interpretation of data. SS ALMEIDA and TM BRAGA COSTA contributed to the conception and design and final version approval of article.

\section{REFERENCES}

1. World Health Organization. Obesity and overweight. Geneva: Organization; 2018 [cited 2020 Jan 3]. Available from: http://www.who.int/mediacentre/factsheets/fs311/en/index.html

2. Prado MTA, Aoyagui TAC, Scarcelli ALM, Fernani DCGL, Massetti T, Silva TD, et al. Anthropometric profile, eating habits and physical activity levels of students in a city in the state of São Paulo. Med Express. 2016;3(6):M160604. https://doi.org/10.5935/medicalexpress.2016.06.04

3. Magalhães TCA, Vieira SA, Priore SE, Ribeiro AQ, Franceschini SCC, Sant'Ana LFR. Fatores associados à dislipidemia em crianças de 4 a 7 anos de idade. Rev Nutr. 2015;28(1):17-28. https://doi.org/10.1590/1415-52732015000100002

4. Instituto Brasileiro de Geografia e Estatística. Pesquisa de Orçamentos Familiares 2008-2009: antropometria e estado nutricional de crianças, adolescentes e adultos no Brasil. Rio de Janeiro: Instituto; 2010 [citado 4 jul 2019]. Disponível em: https://biblioteca.ibge.gov.br/visualizacao/livros/liv45419.pdf

5. Freitas FR, Moraes DEB, Warkentin S, Mais LA, Ivers JF, Taddei JAAC. Maternal restrictive feeding practices for child weight control and associated characteristics. J Pediatr. 2019;95(2):201-8. https://doi.org/10.1016/j. jped.2017.12.009 
6. Rossi CE, Costa LCF, Machado MS, Andrade DF, Vasconcelos FAG. Fatores associados ao consumo alimentar na escola e ao sobrepeso/obesidade de escolares de 7-10 anos de Santa Catarina, Brasil. Ciênc Saúde Coletiva. 2019;24(2):443-54. https://doi.org/10.1590/1413-81232018242.34942016

7. Rocha NP, Milagres LC, Filgueiras MS, Suhett LG, Silva MA, Albuquerque FM, et al. Associação dos padrões alimentares com excesso de peso e adiposidade corporal em crianças brasileiras: estudo Pase-Brasil. Arq Bras Cardiol. 2019;113(1):52-9. https://doi.org/10.5935/abc.20190113

8. Sparrenberger K, Friedrich RR, Schiffner MD, Schuch I, Wagner MB. Ultra-processed food consumption in children from a Basic Health Unit. J Pediatr. 2015;91(6):535-42. https://doi.org/10.1016/j.jped.2015.01.007

9. Ferreira APS, Szwarcwald CL, Damacena GN. Prevalência e fatores associados da obesidade na população brasileira: estudo com dados aferidos da Pesquisa Nacional de Saúde, 2013. Rev Bras Epidemiol. 2019;22:e190024. https:// doi.org/10.1590/1980-549720190024

10. Pereira LJ, Hinnig PF, Di Pietro PF, Assis MAA, Vieira FGK. Trends in food consumption of schoolchildren from 2nd to 5th grade: a panel data analysis. Rev Nutr. 2020;33:e190164. https://doi.org/10.1590/1678-9865202033e190164

11. Vieira DAS, Castro MA, Fisberg M, Fisberg RM. Nutritional quality of dietary patterns of children: are there differences inside and outside school? J Pediatr. 2017;93(1):47-57. https://doi.org/10.1016/j.jped.2016.03.008

12. Bento BMA, Moreira AC, Carmo AS, Santos LC, Horta PM. A higher number of school meals is associated with a less-processed diet. J Pediatr. 2018;94(4):404-9. https://doi.org/10.1016/j.jped.2017.07.016

13. Jaime PC, Stopa SR, Oliveira TP, Vieira ML, Szwarcwald CL, Malta DC. Prevalência e distribuição sociodemográfica de marcadores de alimentação saudável, Pesquisa Nacional de Saúde, Brasil 2013. Epidemiol Serv Saúde. 2015;24(2):267-76. https://doi.org/10.5123/S1679-49742015000200009

14. Pinto A, Santos AC, Lopes $C$, Oliveira A. Dietary patterns at 7 year-old and their association with cardiometabolic health at 10 year-old. Clin Nutr. 2020;39(4):1195-202. https://doi.org/10.1016/j.clnu.2019.05.007

15. Vilela S, Severo M, Moreira T, Oliveira A, Hetherington MM, Lopes C. Association between eating frequency and eating behaviours related to appetite from 4 to 7 years of age: findings from the population-based birth cohort generation XXI. Appetite. 2019;132:82-90. https://doi.org/10.1016/j.appet.2018.10.002

16. Cornwell B, Villamor E, Mara-Plazas M, Marin C, Monteiro CA, Baylin A. Processed and ultra-processed foods are associated with lower-quality nutrient profiles in children from Colombia. Public Health Nutr. 2018;21(1):142-7. https://doi.org/10.1017/S1368980017000891

17. Correa RS, Vencato PH, Rockett FC, Bosa VL. Dietary patterns: are there diferences between children and adolescentes? Ciênc Saúde Coletiva. 2017;22(2):553-62. https://doi.org/10.1590/1413-81232017222.09422016

18. Pinhão $S$, Poínhos R, Franchini $B$, Afonso $C$, Teixeira VH, Moreira $P$, et al. Avaliação da ingestão energética e em macronutrientes da população adulta portuguesa. Rev Port Saúde Pública. 2016;34(3):220-35. https://doi.org/10.1016/j. rpsp.2016.06.004

19. Oliveira A, Jones L, Lauzon-Guillain B, Emmett P, Moreira P, Charles MA, et al. Early problematic eating behaviours are associated with lower fruit and vegetable intake and less dietary variety at 4-5 years of age: a prospective analysis of three European birth cohorts. Br J Nutr. 2015;114(5):763-71. https://doi.org/10.1017/s0007114515002287

20. Lopes RVC, Teixeira JA, Marchioni DM, Villa LL, Giuliano AR, Fisberg RM. Improvement in dietary intake estimates through the combined use of different approaches. Rev Nutr. 2019;32:e180137. https://doi.org/10.1590/1678-98 $65201932 \mathrm{e} 180137$

21. Park Y, Dodd KW, Kipnis V, Thompson FE, Potischman N, Schoeller DA, et al. Comparison of self-reported dietary intakes from the automated self-administered 24-h recall, 4-d food records, and food-frequency questionnaires against recovery biomarkers. Am J Clin Nutr. 2018;107:80-93. https://doi.org/10.1093/ajcn/nqx002

22. Monteiro LS, Hassan BK, Estima CCP, Souza AMS, Verly Junior E, Sichieri R, et al. Food consumption according to the days of the week: National Food Survey, 2008-2009. Rev Saúde Pública. 2017;51:93. https://doi.org/10.11606/ s1518-8787.2017051006053

23. Oliveira MC, Calahani IM, Previdelli AN, Malta MB, Corrente JE, Papini SJ. Aplicação do Índice de Qualidade da Dieta revisado antes e após orientação nutricional. Rev Ciênc Méd. 2015;24(1):29-36. https://doi.org/10.24220/2318-08 97v24n1a2308

24. Galasi-Pacheco LF, Vieira CM, Ferreira MCS, Oliveira MRM. Food practices and their meanings in the daily routine of a university. Rev Nutr. 2019;32:e180208. https://doi.org/10.1590/1678-9865201932e180208 
25. Silva DCA, Frazão IS, Osório MM, Vasconcelos MGL. Percepção de adolescentes sobre a prática de alimentação saudável. Ciênc Saúde Coletiva. 2015;20(11):3299-308. https://doi.org/10.1590/1413-812320152011.00972015

26. Barufaldi LA, Abreu GA, Oliveira JS, Santos DF, Fujimori E, Vasconcelos SML, et al. ERICA: prevalence of healthy eating habits among Brazilian adolescents. Rev Saúde Pública. 2016;50(Suppl1):6s. https://doi.org/10.1590/s01518-8 787.2016050006678

27. Vollmer RL, Baietto J. Practices and preferences: exploring the relationships between food-related parenting practices and child food preferences for high fat and/or sugar foods, fruits, and vegetables. Appetite. 2017;113:134-40. https://doi.org/10.1016/j.appet.2017.02.019

28. Bogea EG, Martins MLB, Carvalho WRC, Arruda SPM, França AKTC, Silva AAM. Padrões alimentares de crianças de 13 a 35 anos de idade e associações com características maternas. Cad Saúde Pública. 2019;35(4)e00072618. https://doi.org/10.1590/0102-311x00072618

29. Kracht CL, Sisson SB, Guseman EH, Hubbs-Tait L, Arnold SH, Graef J, et al. Family eating behavior and child eating patterns differences between children with and without siblings. J Nutr Educ Behav. 2019;51(10):1188-93. https:// doi.org/10.1016/j.jneb.2019.08.004

30. Pedroso J, Toral N, Gubert MB. Maternal attitudes, beliefs and practices related to the feeding and nutritional status of schoolchildren. Rev Nutr. 2019;32:e180184. https://doi.org/10.1590/1678-9865201932e180184

31. Ramos DC, Coelho TCB. Representação social de mães sobre alimentação e uso de estimulantes do apetite em crianças: satisfação, normalidade e poder. Physis. 2017;27(2):233-54. https://doi.org/10.1590/s0103-73312017000200004

32. Chow SC, Shao J, Wang H. Sample size calculations in clinical research. New York: Marcel Dekker; 2008.

33. Ministério da Saúde (Brasil). Orientações para a coleta e análise de dados antropométricos em serviços de saúde: Norma Técnica do Sistema de Vigilância Alimentar e Nutricional. Brasília: Ministério; 2011 [citado 21 Fev 2020]. Disponível em: http://bvsms.saude.gov.br/bvs/publicacoes/orientacoes_coleta_analise_dados_antropometricos.pdf

34. Lorenzato L, Cruz ISM, Braga Costa TM, Almeida SS. Translation and cross-cultural adaptation of a Brazilian version of the Child Feeding Questionnaire. Paidéia. 2017;27(66):33-42. https://doi.org/10.1590/1982-43272766201705

35. Vinholes DB, Assunção MCF, Neutzling MB. Frequência de hábitos saudáveis de alimentação medidos a partir dos 10 Passos da Alimentação Saudável do Ministério da Saúde: Pelotas, Rio Grande do Sul, Brasil. Cad Saúde Pública. 2009;25(4):791-99. https://doi.org/10.1590/S0102-311X2009000400010

36. Assumpção D, Domene SMA, Fisberg RM, Canesqui AM, Barros MBA. Diferenças entre homens e mulheres na qualidade da dieta: estudo de base populacional em Campinas, São Paulo. Ciênc Saúde Coletiva. 2017;22(2):347-58. https://doi.org/10.1590/1413-81232017222.16962015

37. Ferrari TK, Cesar CLG, Alves MCGP, Barros MBA, Goldbaum M, Fisberg RM. Estilo de vida saudável em São Paulo, Brasil. Cad Saúde Pública. 2017;33(1):e00188015. https://doi.org/10.1590/0102-311×00188015

38. Mendes A, Gavioli L, Previdelli AN, Fisberg RM, Marchioni DML. The diet quality index evaluates the adequacy of energy provided by dietary macronutrients. Rev Nutr. 2015;28(4):341-8. https://doi.org/10.1590/1415-5273 2015000400001

39. Andrade SC, Previdelli AN, Cesar CLG, Marchioni DML, Fisberg RM. Trends in diet quality among adolescents, adults and older adults: a population-based study. Prev Med Rep. 2016;4:391-6. https://doi.org/10.1016/j. pmedr.2016.07.010

40. Mendes A, Pereira JL, Fisberg RM, Marchioni DML. Dietary energy was associated with diet quality in Brazilian adults and older adults. Appetite. 2016;97:120-6. https://doi.org/10.1016/j.appet.2015.11.025

41. Grupo de Pesquisa de Avaliação do Consumo Alimentar (São Paulo). Roteiro para o cálculo o Índice de Qualidade da Dieta Revisado (IQD-R). São Paulo: Universidade de São Paulo; 2018 [citado 10 dez 2018]. Disponível em: http:// gac-usp.com.br/wp-content/uploads/2020/01/Roteiro-para-calcular-0-\%C3\%8Dndice-de-Qualidade-da-Dieta_ Revisado-_IQD-R_.pdf

42. International Business Machines Corporation. Statistical Package for Social Sciences. version 23.0 [software]. Chicago: IBM; 2015.

43. StataCorp. Stata Statistical Release 13. [software]. College Station: StataCorp LP; 2013.

44. Statistical Analysis System/Statistical analysis: SAS/STAT ${ }^{\circledR}$ User's Guide. version 9.0. [software]. Cary: SAS Institute Inc.; 2002. 
45. Karp SM, Barry KM, Gesell SB, Po'e EK, Dietrich MS, Barkin SL. Parental feeding patterns and child weight status for Latino preschoolers. Obes Res Clin Pract. 2014;8(1):e88-e97. https://doi.org/10.1016/j.orcp.2012.08.193

46. Pinheiro-Carozzo NP, Oliveira JHA. Comportamento alimentar: um estudo da relação entre IMC de crianças e sua percepção sobre as práticas alimentares parentais. Estud Interdiscip Psicol. 2015;6(1):21-35. https://doi. org/10.5433/2236-6407.2015v6n1p21

47. Coelho HM, Pires AP. Relações familiares e comportamento alimentar. Psic: Teor Pesq. 2014;30(1):45-52. https://doi. org/10.1590/S0102-37722014000100006

48. Sousa NFC, Javorski M, Sette GCS, Pontes CM, Santos AHS, Leal LP. Practices of mothers and caregivers in the implementation of the ten steps for healthy feeding. Texto Contexto Enferm. 2019;28:e20170596. https://doi. org/10.1590/1980-265x-tce-2017-0596

49. Marques MS, Silva JR, Lima CAG, Maia EMGC. Prevalência de sobrepeso e obesidade entre crianças de 7 a 10 anos atendidas em unidade de Estratégia Saúde da Família: ESF. Rev Bras Med Fam Comunidade. 2015;10(37):1-9. https://doi.org/10.5712/rbmfc10(37)1032

50. Salles-Costa R, Barroso GS, Cabral M, Castro MBT. Parental dietary patterns and social determinants of children's dietary patterns. Rev Nutr. 2016;29(4):483-93. https://doi.org/10.1590/1678-98652016000400004

51. Moraeus L, Lissner L, Olsson L, Sjöberg A. Age and time effects on children's lifestyle and overweight in Sweden. BMC Public Health. 2015:15;355. https://doi.org/10.1186/s12889-015-1635-3 